\title{
JUURNAL.RU
}

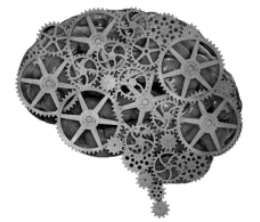

COMPANY GROUP "INTELLEKT"

\author{
Чекулаева Е.Н. \\ Поволжский государственный технологический университет \\ Йошкар-Ола, Россия
}

doi: 10.18411/lj2016-5-5-13

\section{Налоговая оптимизация рисков в организациях}

Российское налоговое законодательство подвержено постоянным изменениям и уточнениям. В отечественные нормативные документы регулярно вносятся поправки, как уточняющие отдельные методы расчета налоговой базы, так и кардинально меняющие принципы организации учета или начисления и уплаты определенных налогов.

Руководителям и главным бухгалтерам компаний зачастую некогда следить за всеми этими нюансами, кроме того, им не всегда удается правильно оценить масштаб тех или иных новшеств и последствия их внедрения для собственного бизнеса. Однако незнание налогового законодательства и неумение правильно использовать законные методы минимизации налоговых выплат приводят к самым серьезным последствиям[3]:

- неэффективному ведению бизнеса;

- наложению всевозможных штрафных санкций;

- возникновению административной или уголовной ответственности для руководителей и собственников бизнеса.

Именно поэтому грамотное налоговое планирование, осуществленное силами профессиональных бухгалтеров аутсорсинговой компании, приобретает все большую популярность среди бизнесменов, предпочитающих вести свое дело на принципах честности и открытости. 
Гармонизация отношений между налоговыми органами и добросовестными налогоплательщиками требует совместных взаимных усилий и соответствующей институциональной среды для ее достижения.

Налоговая оптимизация и управление рисками организации вообще неотделимо от системы финансово - налогового управления, является обязательным элементом эффективного ведения предпринимательской деятельности и должно быть встроено в общую систему управления организации. Недостаточная теоретическая проработка и отсутствие четкой системы методических подходов к налоговой оптимизации и управлению рисками в части налоговых отношений на практике, позволяющей идентифицировать такие риски, своевременно реализовывать превентивные мероприятия, оценивать вероятность разногласий и конфликтов при реализации налоговыми органами различных форм и методов контроля, свидетельствуют о незадействованности всех возможных резервов для совершенствования процесса управления налогообложением с целью увеличения эффективности финансовохозяйственной деятельности организации [2].

Сущность налоговой оптимизации состоит в признанном за каждым налогоплательщиком праве использовать все допускаемые законом средства, пути и методы для максимального сокращения своих налоговых обязательств. Возможность налогового планирования обусловлена наличием в налоговом законодательстве весьма обширной сферы, где нормы права с достаточной точностью не определены или допускается их неоднозначное толкование.

В основе налоговой оптимизации лежит:

- учет основных направлений развития налоговой, бюджетной и инвестиционной политики государства;

- разработка учетной политики предприятия;

- правильное и полное использования всех установленных законом ЛЬГОт; 
- оценка возможностей получения отсрочек и рассрочек по уплате налогов.

Любая организация при налоговой минимизации должна соблюдать требования действующего налогового законодательства, в противном случае действия налогоплательщика будут квалифицированы как налоговое правонарушение. Поэтому налоговая минимизация сопряжена наличием налоговых рисков.

Под рисками налоговой минимизации понимаются возможности понести финансовые потери, связанные с этим процессом, выраженные в денежном эквиваленте. Налоговыми рисками являются [5]:

- риски налогового контроля;

- риски усиления налогового бремени;

- риски уголовного преследования.

Проводить минимизацию налогообложения лучше всего задолго до регистрации организации, так как будущая система налогообложения компании определяется в момент создания. К тому же на данном этапе минимизация налогообложения является наиболее эффективной, так как будут отсутствовать ошибки или их количество будет намного меньше, чем в будущем периоде.

Любое налоговое планирование связано с предпринимательскими рисками. Налоговые органы не поощряют действия налогоплательщиков, преследующие снижение налоговой нагрузки, даже если такие действия формально не противоречат законодательству. И это вполне понятно, поскольку цель государственного бюджета состоит в максимальном увеличении налоговых поступлений.

Поэтому любому предприятию необходимо проводить ряд мероприятий по снижению налоговых рисков, а именно [4]:

- снижение рисков на предприятии - оно включает ежегодную актуализацию налоговой политики компании, учет инвестиционных и управленческих рисков; 
- тесное взаимодействие с налоговыми органами - регулярная сверка налоговых расчетов, письменных запросы по особенностям правоприменения отдельных положений Налогового кодекса и иных нормативных актов;

- регулярная работа с контрагентами компании - текущий мониторинг заключаемых договоров.

Результатом таких мероприятий, проведенных предприятиями, станет снижение общей налоговой нагрузки, минимизация возможных налоговых рисков, а также практически полное исключение претензий со стороны фискальных органов. Всесторонняя оценка налоговых рисков со стороны участников налогового процесса как налогоплательщиков, так и государственных органов приведет к росту налоговой дисциплины и снижению количества и объема налоговых споров [4]. 


\section{Литература:}

1. Гончаренко Л.И. Налоговые риски: теоретический взгляд на содержание понятия и факторы возникновения // Налоги и налогообложение. - 2009. №1.

2. Гордеева О.В. К вопросу об управлении налоговыми рисками // Налоги. 2008. - №2.

3. Ц Цыркунова Г.А. Налоговые риски: сущность и классификация / Г.А. Цыркунова, М.И. Мигунова // Финансы и кредит. - 2005. - №33.

4. Фадеев Д.Е. Актуальные вопросы развития налоговой системы /Д.Е. Фадеев // Налоᄀговый вестник.- 2010.- № 5.- С.120-125.

5. Чекулаева Е.Н. Управление налоговыми рисками в системе урегулирования отношений с налогоплательщиками/Е.Н. Чекулаева// Монография. - Перо.- 2016 г. - С. 170 с. 